\title{
Comparative Study of Various Thermal Analyses of Smart Windows in Cubic Building Design
}

\author{
El Mehdi El Khattabi ${ }^{1,2, *}$, Mohamed Mharzi ${ }^{1,2}$, Mohammed Zouini ${ }^{1,2}$ and Kęstutis Valančius ${ }^{3}$ \\ ${ }^{1}$ Laboratory for Integration of Advanced Systems and Technologies-University Sidi Mohamed ben Abdellah-Faculty of Sciences Dhar El \\ Mehraz, Fez, (Morocco) \\ ${ }^{2}$ Laboratory of the Thin Layers and Surface Treatment By Plasma ENS-Fès. Fez 30000, Morocco \\ ${ }^{3}$ Vilnius Gediminas Technical University, Faculty of Environmental Engineering, Lithuania, Vilnius
}

Received 29 March 2018; Accepted 5 November 2018

\begin{abstract}
This paper presents a thermal analysis of compounds called smart windows in typical building design; such windows are covered with a vanadium dioxide film doped with tungsten and are characterized by their phase transition which makes the transmission coefficient high for low temperatures and low for high temperatures. This leads to the natural optimization of thermal comfort in summer and winter through a decrease in solar radiation transmission in the summer and an increase in it in the winter. A comparative study of four types of glass has been carried out both in summer and winter: simple glass $\mathrm{SiO} 2$, dioxide of vanadium un-doped glass, vanadium dioxide glass doped with 3\% tungsten and 5\% tungsten in order to evaluate their effect on the interior temperature of the building. For these reasons, a thermal model in the dynamic state has been developed to assess the thermal performance in such a building and to evaluate the effect of these windows on thermal comfort in terms of heat flow, density and internal temperature. The analysis was carried out having taken into account the external weather conditions of Fez, such as radiation, natural convection, air exchange, and the outdoor temperature as well as different parameters of the building envelope.
\end{abstract}

Keywords: Thermal analysis; Smart windows; Vanadium dioxide; Dynamic model; Thermal comfort conditions.

\section{Introduction}

Global attention has recently been focused on problems concerning climate change which has been noted by many researchers (e.g. W. Neil Adger et al., 2017) [1], especially the possibility of reducing global warming by $2^{\circ} \mathrm{C}$ in 2100 . A lot of effort has been put into this objective which has been pressuring decision-makers to respond to and to support all innovative initiatives [2, 3]; consequently, the researchers are moving towards the use of new and nano technologies known as "green-tech". As mentioned in the book by Geoffrey B et al., 2011 [4], this can open many possibilities of reducing energy consumption and improving thermal comfort. These two factors have been the subject of studies and discussions of international programs and organizations such as the UN Environment Programme and the International Energy Agency (IEA) [5, 6]. The paper's authors have also analysed this in their previous research, having described the different ways to ensure this comfort by consuming less energy inside the building [7].

According to the International Energy Agency (IEA) [6], the building sector currently represents a third of the worldwide consumption of energy. This has motivated decision-makers and researchers to search for ways to improve energy performance inside passive and active element buildings. The implementation of intelligent home automation also makes it possible to control the behaviour of consumers that have one of the most complex parameters for

*E-mail address: mehdienerg@gmail.com

ISSN: $1791-2377 @ 2018$ Eastern Macedonia and Thrace Institute of Technology. All rights reserved. doi:10.25103/jestr.115.10 managing energy consumption in buildings [8-9], including structures, lighting, energy production system, etc. and could significantly reduce its $\mathrm{CO} 2$ emissions thanks to green technologies, since the majority of the residents of industrialized countries spend the majority of their time inside the buildings and in their vehicles, as a comparative study by J.A. Leech 2002 [10] of the activity time of citizens of the largest industrial countries, Canada and the United States, has demonstrated. Moreover, studies have shown that smart windows in buildings [11-13] are regarded as suitable means to save energy and ensure thermal comfort.

"Smart windows" are made from glass [14-17] that gives them the advantage of both allowing good radiation ingression in the winter while remaining transparent and preventing the heat from penetrating the dwellings in summer while preserving a good view of the outside. The aforementioned windows, thus, make it possible to create energy savings in winter; they are made from materials known as smart which have the capacity to receive information about their environment and to interact with this environment by changing their properties (electric, optical, mechanical, etc) in response to the external stimuli. One of such materials is vanadium dioxide, $\mathrm{VO}_{2}$. It was discovered more than 50 years ago by F.J. Morin [18]. He highlighted its reversible phase transition [19-25] from the semiconductor state to its metal state at a transition temperature $\mathrm{Tc}=68^{\circ} \mathrm{C}$. This phase transition then generates the changes of the optical properties of this material [26-30] within the infra-red range. Within this framework, one observes an important variation in the transmission of $\mathrm{VO} 2$ film between the insulating state, characterized by a high transmission $\left(42 \%\right.$ at $\left.5^{\circ} \mathrm{C}\right)$, and the metal state, where the transmission is very weak $\left(5 \%\right.$ at $\left.100^{\circ} \mathrm{C}\right)$. Recently, a lot of 
research has been focused on this material from the perspective of the development of new technologies and especially smart windows. To realize this application in everyday life, it is necessary to lower the critical temperature Tc of the vanadium dioxide by doping it with various elements [31-35]. Indeed, doping the thin layer of $\mathrm{VO}_{2}$ with different amounts of tungsten (W) [36] lowers the temperature of transition to $28^{\circ} \mathrm{C}$.

Previous research has contributed to the improvement of smart glass by developing a thermal model which makes the glass flexible with regards to weather changes and adapts to ensure the thermal comfort of the building. This has been achieved by analysing the percentage of doping determined according to the indoor thermal comfort needs and weather conditions.

Finally, in this article, the authors study the possibility of replacing electric air conditioning in buildings with green air conditioning based on smart windows by adding thin layers of VO2 to these windows.

\section{Numerical procedure}

The thermal properties of the glass are variables in the function of glass temperature, making it difficult to use certain diagnostic thermal tools (i.e. carry out a lot of simulation for each transmission coefficient) that use constant physical thermal properties of construction materials.

To show the effect of these smart windows, a numerical model in dynamic state has been developed. It is based on three sections: external conditions, properties of materials and internal conditions. Each section has been detailed as a function of local variables, building parameters and internal coupling in order to accurately analyze the methodology which leads to the optimization of thermal comfort conditions in summer and winter.

\subsection{External conditions}

Radiation incident to the external walls is evaluated using equations reported in Solar Thermal, Courses and Exercises by Jannot Y [37], and validated by Bekkouche et al [38].

The isotropic solar model was adjusted to evaluate the solar irradiation $\mathrm{G}$ at each iteration using the same step of time, $\Delta \mathrm{t}$, in accordance with the thermal model.

Direct solar radiation received by the surface is defined as:

$$
\mathrm{G}(\mathrm{t})=\mathrm{CI} \mathrm{E}_{\mathrm{sol}} \exp (-\mathrm{ER} \mathrm{m} \mathrm{TL})
$$

\section{Where:}

Esol is the solar constant; it is expressed as function of the day number by:

$$
\mathrm{E}_{\mathrm{sol}}=1367 \times\left(1+0.0334 \times \frac{\cos (\mathrm{j}-2.7206)}{365.25}\right)
$$

$\mathrm{CI}$ is the incidence coefficient expressed as follows:

$$
\mathrm{CI}=\sin (\mathrm{i}) \times \cos (\mathrm{h}) \times \cos (\mathrm{o}-\alpha) \times \cos (\mathrm{i}) \times \sin (\mathrm{h})
$$

The coefficient $\mathrm{CI}$ depends on the height $\mathrm{h}$ and the azimuth $\alpha$ of the sun, the direction o and the inclination $i$ of the external partitions of building. These parameters are related to the angular hour $\mathrm{w}$, which is expressed as a function of the time step $\Delta \mathrm{t}$, and calculated by using:

$$
\mathrm{W}=15(\mathrm{t}-12 \Delta \mathrm{t}) / \Delta \mathrm{t}
$$

ER is the integral Rayleigh optical thickness:

$\mathrm{ER}=1 /(0.9 \mathrm{~m}+9.4)$

$\mathrm{m}$ is the atmospheric mass and is expressed as:

$$
\mathrm{m}=\frac{\mathrm{P}_{\mathrm{atm}}}{101325 \times \sin (\mathrm{h})+15198.75 \times(3.885+\mathrm{h})^{-1.253}}
$$

$\mathrm{T}_{\mathrm{L}}$ is the turbidity factor calculated using:

$$
\mathrm{T}_{\mathrm{L}}=2.4+14.6 \times \mathrm{B}=0.4 \times(1+2 \times \mathrm{B}) \times \ln \left(\mathrm{P}_{\mathrm{v}}\right)
$$

For our latitude we assume that the atmospheric turbidity B is 0.05 (Urban area).

This paper bases its findings on heat balance assuming that temperature distribution moves only in one direction; the steam saturation pressure of water is evaluated for a constant temperature inside the building. The expression of the convective transfer coefficient is calculated by following the correlation which depends on the temperature difference between the surface and air hconv $=1.31(\mathrm{DT} / \mathrm{L}) 1 / 3$ for this condition $\mathrm{Gr} \times \operatorname{Pr}>109[39,40]$. In addition to this, irradiative transfer coefficient and convective transfer coefficient are combined, as well as the convection due to wind speed [39]. All possible meteorological disturbances have been investigated in this paper.

Airflow $Q_{V}(\mathrm{~m} 3 / \mathrm{s})$ through an orifice is expressed, regardless of its size and shape, depending on the pressure difference between the two atmospheres connects and geometric characteristics of the orifice or element which has interstices [41].

\subsection{Material properties of smart windows}

Thermo-chromic materials are defined as materials the optical properties of which change according to the temperature in a reversible or quasi-reversible way.

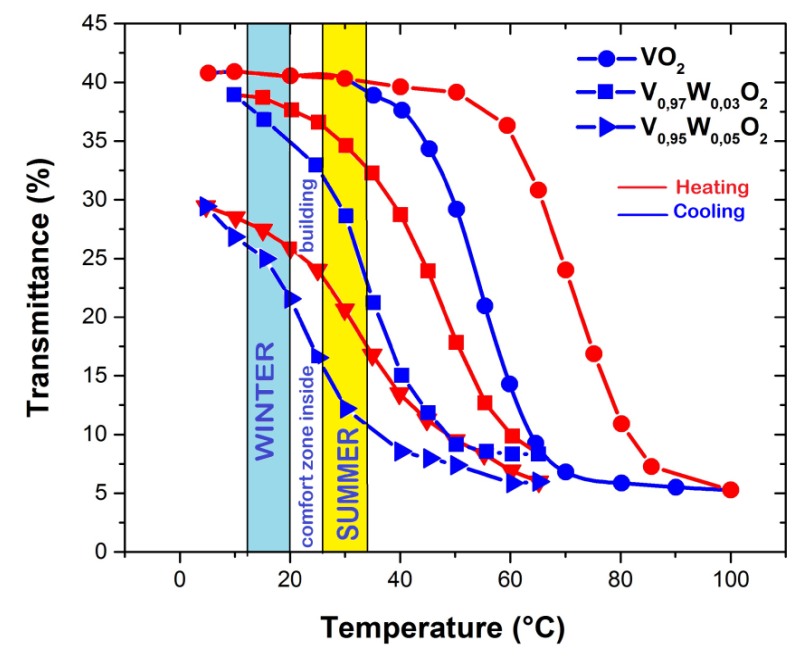

Fig. 1. Transmittance coefficient of glazing

A smart thermo-chromic window [42-44] is a type of glass made from thermo-chromic materials that can adapt the energy inside buildings according to the energy needs through the amount of doping. These materials vary, but vanadium dioxide VO2 is the most prominent. Based on the transition temperature Tc of vanadium oxides, it is noticed 
that it can undergo a transition from the reversible phase of the semiconductor state to its metal state at a transition temperature $\mathrm{Tc}=68^{\circ} \mathrm{C}$; this temperature is close to the ambient temperature.

The thermo-chromic effect of vanadium dioxide is caused by the phase shift, accompanied by the behavioral change of the semiconductor, the metal making the material transparent at lower temperatures $\left(\mathrm{T}<68{ }^{\circ} \mathrm{C}\right)$ and absorbent at higher temperatures $\left(\mathrm{T}>68{ }^{\circ} \mathrm{C}\right)$. Indeed, this phase transition occurs in a very short amount of time, about a few nanoseconds. Doping VO2 with elements such as molybdenum, tungsten or niobium [36] and lowering its transition temperature to the ambient temperature makes it possible to modify this transition temperature Tc.

\subsection{Internal temperature coupling}

In order to precisely assess the thermal performance inside the building, it is necessary to determine the internal temperature at the first step since this variable allows to determine all other thermal functions that affect thermal behaviors in terms of passive and active elements, such as air exchange, thermal flux through walls, roof and windows as well as heating and cooling loads. Thus, the internal temperature equation that includes all the parameters and variables that influence the thermal performance inside buildings has been developed in dynamic state:

$$
\begin{aligned}
& \frac{\mathrm{m}_{\text {air }} \cdot \mathrm{c}_{\text {air }}}{\Delta \mathrm{t}} \cdot\left(\mathrm{T}_{\mathrm{in}}^{\mathrm{k}+1}-\mathrm{T}_{\mathrm{in}}^{\mathrm{k}}\right)=\left(\sum_{\mathrm{i}=1}^{\mathrm{n}} \frac{\mathrm{S}_{\mathrm{i}}}{\mathrm{R}_{\mathrm{ci}(\mathrm{n}+1)}}\right) \cdot\left(\mathrm{T}_{\mathrm{n}}^{\mathrm{k}}-\mathrm{T}_{\mathrm{in}}^{\mathrm{k}}\right)+ \\
& +\mathrm{F}_{\mathrm{s}} \cdot \mathrm{G}_{\mathrm{w}}^{\mathrm{k}}+\mathrm{U}_{\mathrm{w}} \cdot \mathrm{S}_{\mathrm{w}} \cdot\left(\mathrm{T}_{\mathrm{ex}}^{\mathrm{k}}-\mathrm{T}_{\mathrm{in}}^{\mathrm{k}}\right)+\left(\frac{\rho_{\text {air }} \cdot \mathrm{c}_{\text {air }} \cdot \mathrm{Q}_{\mathrm{v}}}{3600}\right) \cdot\left(\mathrm{T}_{\mathrm{ex}}^{\mathrm{k}}-\mathrm{T}_{\mathrm{in}}^{\mathrm{k}}\right) \\
& \mathrm{T}_{\mathrm{in}}^{\mathrm{k}+1}=\mathrm{A} \cdot \mathrm{T}_{\mathrm{ex}}^{\mathrm{k}}+\mathrm{B} \cdot \mathrm{T}_{\mathrm{n}}^{\mathrm{k}}+(1-(\mathrm{A}+\mathrm{B})) \cdot \mathrm{T}_{\mathrm{in}}^{\mathrm{k}}+\mathrm{C} \cdot \mathrm{G}_{\mathrm{w}}^{\mathrm{k}}
\end{aligned}
$$

With: $A=\left(\frac{D t}{r_{\text {air }} c_{p_{\text {air }}}}\right)\left(U_{w} \cdot S_{w}+0.34 . Q_{v}\right)$ $\mathrm{B}=\left(\frac{\Delta \mathrm{t}}{\mathrm{m}_{\text {air }} \cdot \mathrm{c}_{\text {air }}}\right) \cdot \sum_{\mathrm{i}=1}^{\mathrm{n}} \frac{\mathrm{S}_{\mathrm{i}}}{\mathrm{R}_{\mathrm{ci}(\mathrm{n}+1)}}$ and $\mathrm{C}=\left(\frac{\Delta \mathrm{t}}{\mathrm{m}_{\text {air }} \cdot \mathrm{c}_{\text {air }}}\right) \cdot \mathrm{F}_{\mathrm{s}}$
Where n, Si, Rci(n+1), Tk, Fs, Gw, Uw, Sw and Qv are, respectively, the total number of the building external partitions, the surface of the considered partition, the inner thermal resistance of the partition, the inner layer temperature of the iteration $\mathrm{k}$ (time steps) determined using the discretization model, the solar factor, direct solar radiation on windows of the iteration $\mathrm{k}$ calculated using the solar model, the total thermal transmittance of the total surface of the windows and the air flow rate.

The script is validated using paper [38]. The validation takes into account all the external and internal conditions and parameters considered in the study such as the solar radiation incident to the walls, external air temperature, the dimensions of the building as well as the thermal properties of construction materials. In this comparison study we assume that the absorption coefficient of cement is 0.4 .

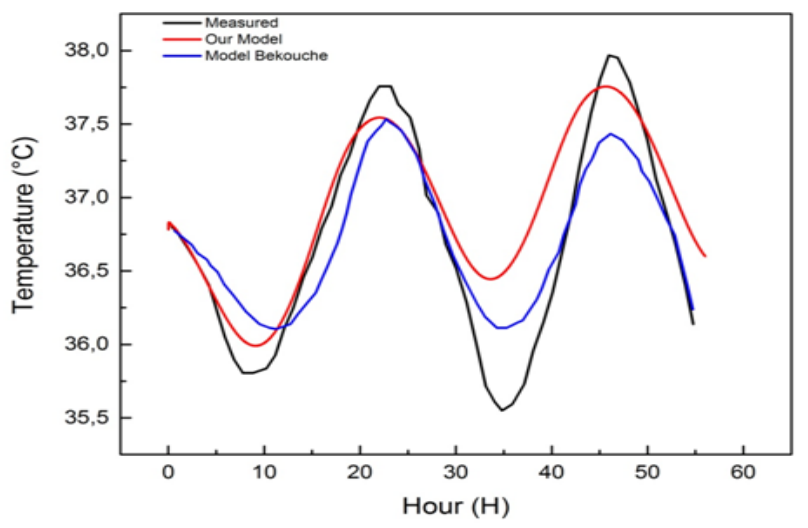

Fig. 2. Simulated and measured temperature inside room

\section{Results and discussion}

The building studied in this paper is located in Fez (34 $03^{\circ}$ $00^{\prime \prime}$ North, $4^{\circ} 58^{\prime} 59^{\prime \prime}$ West). This city, located in the plain of Sais, between the Rif, in the North and the Middle Atlas in the South, is affected by the nearby mountain slope.

Table 1. The monthly variation of temperature in the city of Fez

\begin{tabular}{l|c|c|c|c|c|c|c|c|c|c|c|c}
\hline & Jan & Feb & Mar & Apr & May & June & July & August & Sept & Oct & Nov & Dec \\
\hline Max & $16^{\circ} \mathrm{C}$ & $17^{\circ} \mathrm{C}$ & $20^{\circ} \mathrm{C}$ & $23^{\circ} \mathrm{C}$ & $26^{\circ} \mathrm{C}$ & $31^{\circ} \mathrm{C}$ & $36^{\circ} \mathrm{C}$ & $36^{\circ} \mathrm{C}$ & $32^{\circ} \mathrm{C}$ & $26^{\circ} \mathrm{C}$ & $21^{\circ} \mathrm{C}$ & $16^{\circ} \mathrm{C}$ \\
Min & $4^{\circ} \mathrm{C}$ & $5^{\circ} \mathrm{C}$ & $8^{\circ} \mathrm{C}$ & $9^{\circ} \mathrm{C}$ & $12^{\circ} \mathrm{C}$ & $15^{\circ} \mathrm{C}$ & $18^{\circ} \mathrm{C}$ & $18^{\circ} \mathrm{C}$ & $16^{\circ} \mathrm{C}$ & $13^{\circ} \mathrm{C}$ & $8^{\circ} \mathrm{C}$ & $6^{\circ} \mathrm{C}$ \\
\hline
\end{tabular}

This building is a cubic structure with the surface area of $25 \mathrm{~m} 2$ of each facade; all walls are exposed to solar radiation. The glass on the southern and eastern walls comprises a surface of $12.56 \mathrm{~m}^{2}$ and $13 \mathrm{~m}^{2}$ for the western wall. Table 1 and Table 2 summarize the constitution and the thermo-physical properties of the various elements of the envelope.

The envelope structure and materials used are listed in Tables 1 to 2 , their type and properties are defined in accordance with the Moroccan construction rules, taken from a database of materials developed by the Moroccan Agency of Energy Efficiency

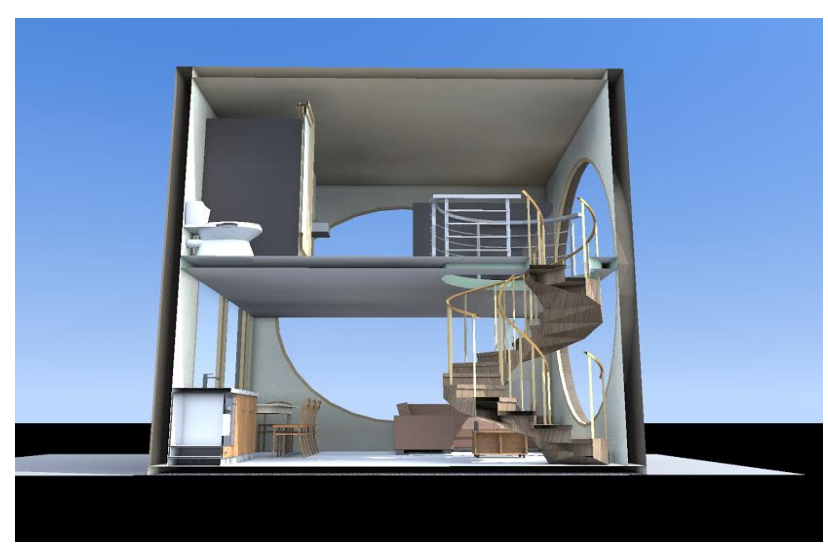

Fig. 3. Simulation of the studied building 


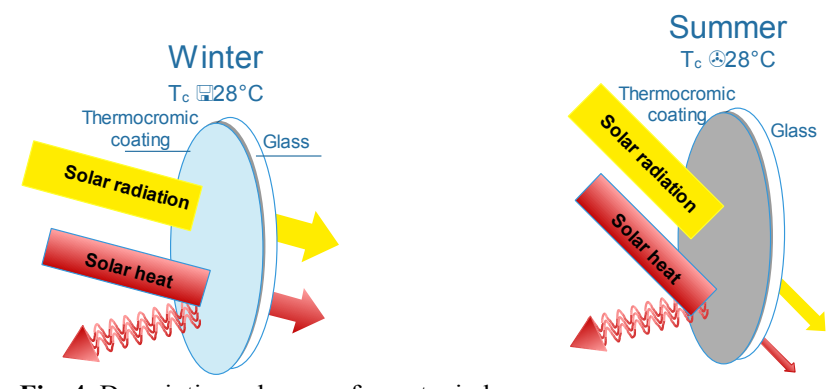

Fig. 4. Descriptive schemes of smart windows

Table 2. Thermo-physical properties of the components of external walls

\begin{tabular}{l|c|c|c|c}
\hline & $\begin{array}{c}\text { Thickness } \\
(\mathbf{c m})\end{array}$ & $\begin{array}{c}\text { Thermal } \\
\text { capacity } \\
(\mathbf{k J} / \mathbf{k g ~ K})\end{array}$ & $\begin{array}{c}\text { Thermal } \\
\text { conductivity } \\
(\mathbf{W} / \mathbf{m ~ K})\end{array}$ & $\begin{array}{l}\text { Density } \\
\left(\mathbf{k g} / \mathbf{m}^{\mathbf{3}}\right)\end{array}$ \\
\hline $\begin{array}{l}\text { Cement } \\
\text { mortar }\end{array}$ & 1,5 & 1 & 1,15 & 1700 \\
\hline Brick & 40 & 0,875 & 1,15 & 1800 \\
\hline Plaster & 1,5 & 1 & 0,4 & 1500 \\
\hline
\end{tabular}

Table 3. Thermo-physical properties of roof components

\begin{tabular}{l|c|c|c|c}
\hline & $\begin{array}{c}\text { Thickness } \\
(\mathbf{c m})\end{array}$ & $\begin{array}{c}\text { Thermal } \\
\text { capacity } \\
(\mathbf{k J} / \mathbf{k g ~ K})\end{array}$ & $\begin{array}{c}\text { Thermal } \\
\text { conductivity } \\
(\mathbf{W} / \mathbf{m} \mathbf{K})\end{array}$ & Density \\
$\left(\mathbf{k g} / \mathbf{m}^{\mathbf{3}}\right)$ \\
\hline Floor tile & 2 & 0.7 & 1.75 & 2300 \\
\hline Mortar & 15 & 0.65 & 1.75 & 1700 \\
\hline Concrete & 20 & 1 & 1.15 & 2100 \\
\hline Plaster & 1.5 & 1 & 0.4 & 1500 \\
\hline
\end{tabular}

The diagnosis is based on the experimental results which show the distribution of window transmission coefficient in function of temperature [36], taking into account only the temperature for the periods summer/winter.

Four types of glass have been studied in the summer: simple glass $\mathrm{SiO} 2$, vanadium dioxide of un-doped glass, vanadium dioxide glass doped with $3 \%$ tungsten and $5 \%$ tungsten in order to evaluate their effect on the interior temperature in the building as well as to identify the optimal choice that would allow to achieve thermal comfort conditions summer or winter.

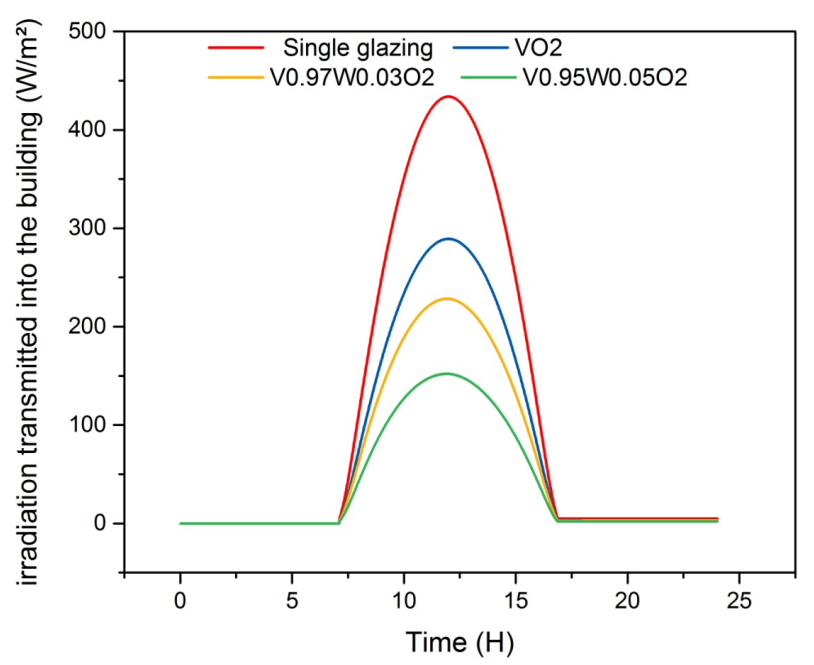

Fig. 5. Radiation transmitted to the building under the weather conditions in Fez in January $1^{\text {st }}$

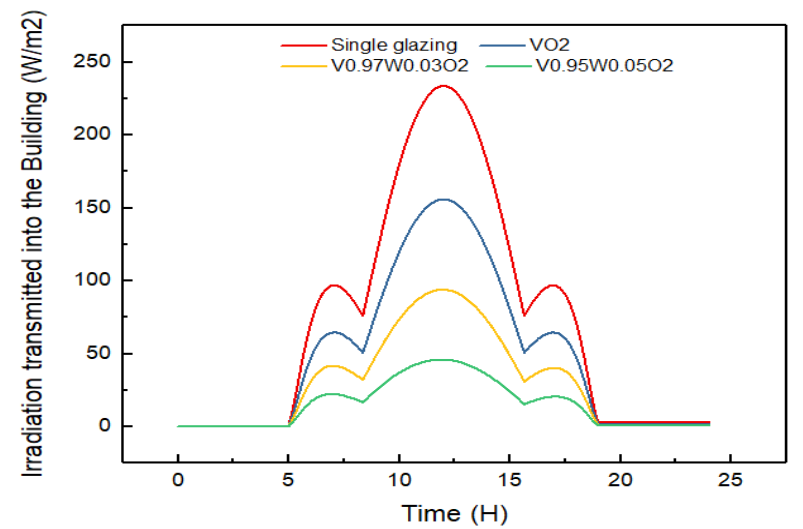

Fig. 6. Radiation transmitted to the building under the weather conditions in Fez in June $30^{\text {th }}$

The density of the flux entering the building via the glass almost doubles in the winter $\left(450 \mathrm{~W} / \mathrm{m}^{2}\right)$ compared to the summer $\left(240 \mathrm{~W} / \mathrm{m}^{2}\right)$ in the case of simple glass $\mathrm{SiO} 2$ under the meteorology conditions in Fez that is due mainly to the angle formed by the solar radiation with the perpendicular of a glass surface; moreover, in Fig. 6 the solar radiation transmitted by the glass directed towards the northern direction appears only in the summer, because the periods of available sunshine are longer in the summer and shorter in the winter; the table below proves the thermal density entering the building for each type of pane.

Table 4. Radiation transmitted within the building $\left(\mathrm{W} / \mathrm{m}^{2}\right)$

\begin{tabular}{l|l|c}
\hline & \multicolumn{2}{l}{$\begin{array}{l}\text { Summer } \\
\text { Winter }\end{array}$} \\
\hline Glass & $\begin{array}{l}\text { Radiation } \\
\text { transmitted }(\mathrm{W} / \mathrm{m}\end{array}$ & $\begin{array}{c}\text { Radiation } \\
\text { transmitted }\left(\mathrm{W} / \mathrm{m}^{2}\right)\end{array}$ \\
& $\left.{ }^{2}\right)$ & 440 \\
Simple $\mathbf{S i O} \mathbf{O}_{\mathbf{2}}$ & 230 & 290 \\
$\mathbf{V O}_{\mathbf{2}}$ & 150 & 230 \\
$\mathbf{V}_{\mathbf{0 . 9 7}} \mathbf{W}_{\mathbf{0 . 0 3}} \mathbf{O}_{\mathbf{2}}$ & 90 & 140 \\
$\mathbf{V}_{\mathbf{0 . 9 5}} \mathbf{W}_{\mathbf{0 . 0 5}} \mathbf{O}_{\mathbf{2}}$ & 40 & \\
\hline
\end{tabular}

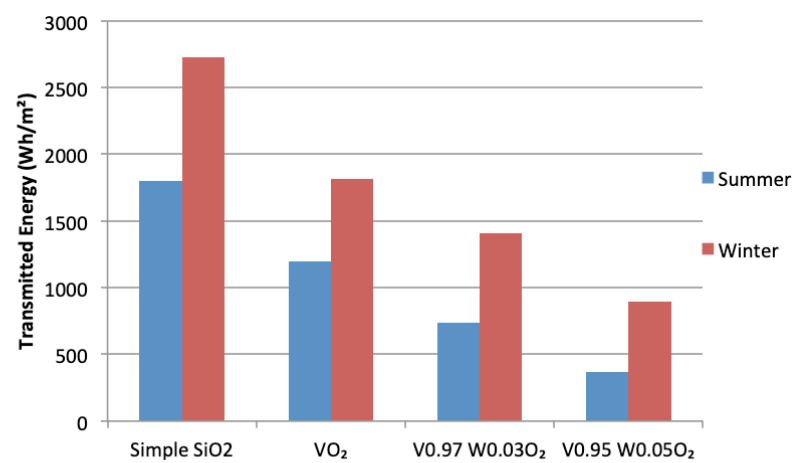

Fig. 7. Transmitted energy in the summer and the winter

This study aims to increase the maximum heat in winter and decrease it in summer without using any active elements (heating and cooling loads). This means that the selected construction materials choice should be elements that will transmit the minimum difference of energy between summer and winter in this regard, as shown in Fig. 7, vanadium dioxide glass doped with $5 \%$ tungsten (V0.95W0.05O2) presents the optimal value in terms of energy transmitted, with $525 \mathrm{Wh} / \mathrm{m}^{2}$. 
El Mehdi El Khattabi, Mohamed Mharzi, Mohammed Zouini and Kęstutis Valančius/

Journal of Engineering Science and Technology Review 11 (5) (2018) 86 - 92

Table 5. Different energy values transmitted for each type of glazing in summer/winter

\begin{tabular}{l|c|c|c|c}
\hline & $\begin{array}{c}\text { Simple } \\
\mathbf{S i O}_{\mathbf{2}}\end{array}$ & $\mathbf{V O}_{\mathbf{2}}$ & $\begin{array}{c}\mathbf{V}_{\mathbf{0 . 9 7}} \\
\mathbf{W}_{\mathbf{0 . 0 3}} \mathbf{O}_{\mathbf{2}}\end{array}$ & $\begin{array}{c}\mathbf{V}_{\mathbf{0 . 9 5}} \\
\mathbf{W}_{\mathbf{0 . 0}} \mathbf{O}_{\mathbf{2}}\end{array}$ \\
\hline $\begin{array}{l}\text { Transmitted energy in } \\
\text { eummer }\left(\mathbf{W h} / \mathbf{m}^{2}\right)\end{array}$ & 1797 & 1198 & 737 & 371 \\
$\begin{array}{l}\text { Transmitted energy in } \\
\text { winter }\left(\mathbf{W h} / \mathbf{m}^{2}\right)\end{array}$ & 2728 & 1818 & 1404 & 896 \\
Thermal difference & 931 & 620 & 667 & 525 \\
\hline
\end{tabular}

To show the effect of various phenomena such as thermal inertia, phase shift, variations in temperature amplitude, the effect of this glass on the thermal behavior of this building in terms of internal temperature was studied in 5 typical days in January and June.

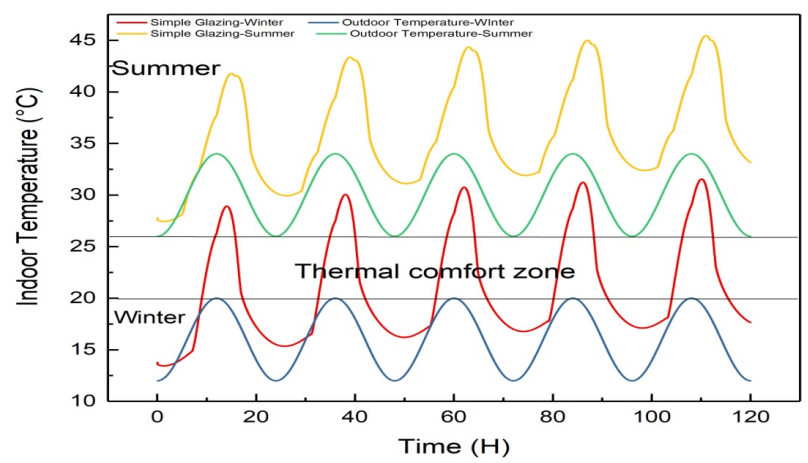

Fig. 8. The effect of simple $\mathrm{SiO} 2$ glass on the internal temperature

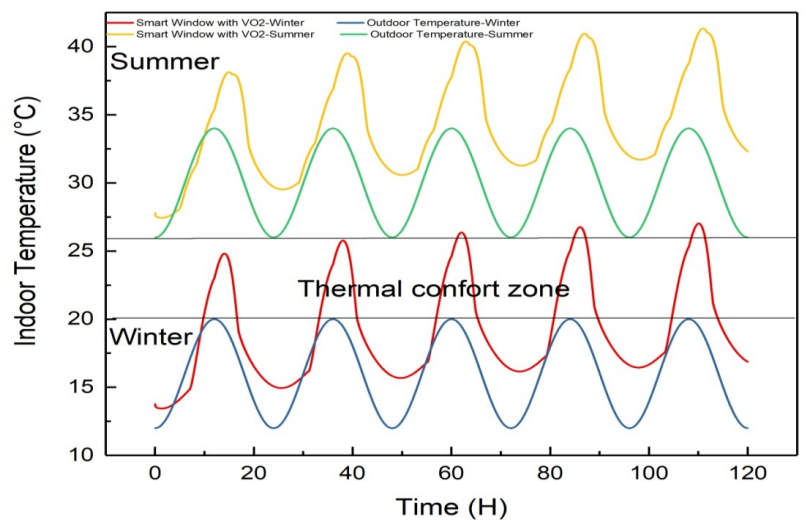

Fig. 9. The effect of un-doped vanadium glass on the internal temperature

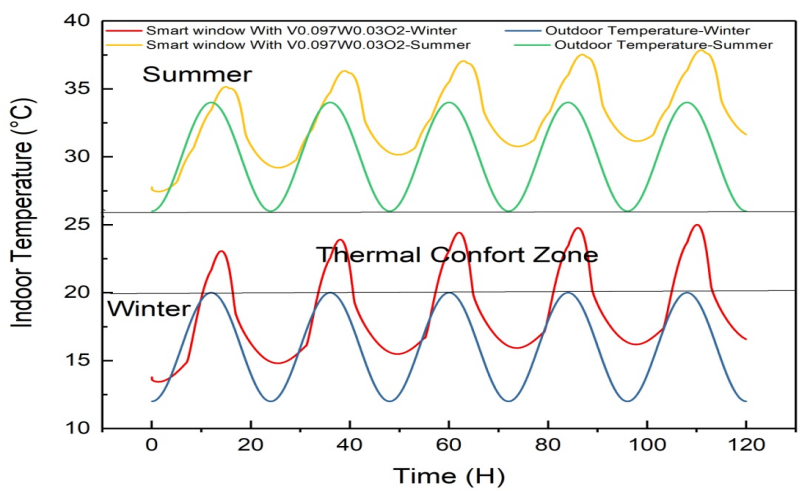

Fig. 10. The effect of vanadium glass doped with $3 \%$ tungsten on the internal temperature

It was noticed that the internal temperature was higher than the external temperature in summer and winter period for all cases due to the transmission of solar radiation through windows (all windows are exposed to the sun). The effect of shading had not been considered, therefore, this study has been performed in a fully sunlit environment, which explains the increase of the internal temperature in both periods. For example, vanadium dioxide glass doped with $5 \%$ tungsten $(\mathrm{V} 0.95 \mathrm{~W} 0.05 \mathrm{O} 2)$ can be transmitted at 14 $\mathrm{kWh}$ /day of energy in summer, and $34 \mathrm{kWh} /$ day in winter periods.

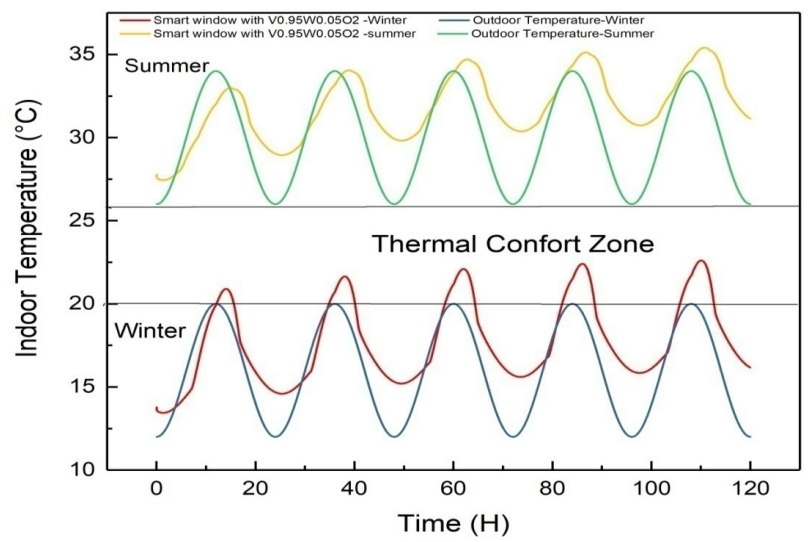

Fig. 11. The effect of vanadium glass doped with $5 \%$ tungsten on the internal temperature

It was noticed that, as shown in Figure 8 , in the case of simple glass the interior temperature in summer exceeded $42^{\circ} \mathrm{C}$ with a tendency of rising $1{ }^{\circ} \mathrm{C}$ per day and the thermal phase shift of 2.5 hours which caused the building to overheat. In the winter the temperature increased to $28^{\circ} \mathrm{C}$ with the thermal phase shift of about 1.5 hours compared to the outside temperature; both summer and winter zones are far from the thermal comfort zone.

The glass with a thin layer of un-doped vanadium dioxide $\mathrm{VO} 2$ led to the internal temperature to drop to $38^{\circ} \mathrm{C}$ in summer with the thermal phase shift of 3 hours compared to the outside temperature (Fig. 9). In the winter, the internal temperature reached $25^{\circ} \mathrm{C}$ with a thermal phase shift of 2 hours compared to the outside temperature.

In the case of glazing with a thin layer of $\mathrm{VO} 2$ doped with 3\% tungsten, presented in Fig. 10, the temperature decreased to $35^{\circ} \mathrm{C}$ in summer, with a thermal phase shift of 4 hours compared to the outside temperature. In winter, the internal temperature decreased to $23^{\circ} \mathrm{C}$ with a thermal phase shift of about 4 hours.

Glass with a thin layer of vanadium dioxide doped with $5 \%$ tungsten caused the internal temperature to drop to $33^{\circ} \mathrm{C}$ in summer, and a thermal phase shift of 4 hours compared to the outside temperature. In winter, the internal temperature of the building reached $21^{\circ} \mathrm{C}$ and the thermal phase shift compared to the outside temperature was 4 hours.

The table below summarizes the thermal performance of each type of glass used.

Table 6. Thermal performance of each type of glass in summer and winter

\begin{tabular}{|c|c|c|c|c|}
\hline & \multicolumn{2}{|c|}{ Summer } & \multicolumn{2}{|c|}{ Winter } \\
\hline Glass & $\begin{array}{c}\text { Thermal } \\
\text { phase shift }\end{array}$ & $\begin{array}{c}\text { Internal } \\
\text { temperature }\end{array}$ & $\begin{array}{c}\text { Thermalphase } \\
\text { shift }\end{array}$ & $\begin{array}{c}\text { Internal } \\
\text { temperature }\end{array}$ \\
\hline $\begin{array}{l}\text { Simple } \\
\mathrm{SiO}_{2}\end{array}$ & 2.5 hours & $42^{\circ} \mathrm{C}$ & 1.5 hours & $28^{\circ} \mathrm{C}$ \\
\hline $\mathrm{VO}_{2}$ & 3 hours & $38^{\circ} \mathrm{C}$ & 2 hours & $25^{\circ} \mathrm{C}$ \\
\hline $\begin{array}{l}V_{0.97} \\
W_{0.03} O_{2}\end{array}$ & 4 hours & $35^{\circ} \mathrm{C}$ & 3 hours & $23^{\circ} \mathrm{C}$ \\
\hline $\begin{array}{l}V_{0.95} \\
W_{0.05} O_{2}\end{array}$ & 4 hours & $33^{\circ} \mathrm{C}$ & 4 hours & $21^{\circ} \mathrm{C}$ \\
\hline
\end{tabular}




\section{El Mehdi El Khattabi, Mohamed Mharzi, Mohammed Zouini and Kęstutis Valančius/}

Journal of Engineering Science and Technology Review 11 (5) (2018) 86 - 92

Glass covered with a thin layer of vanadium dioxide doped with $5 \%$ of tungsten represents a minimal value of temperature in winter because of its low coefficient of transmission and also of its thermal phase shift which is about 4 hours in summer.

\section{Conclusion}

In this paper, a thermal analysis of a cubic room with smart windows has been performed, taking into consideration the weather conditions in Fez. The aim of this analysis was to compare the effect of these windows on the thermal behavior of the building in terms of internal temperature, phase shift, transmitted energy and transmitted power in summer and winter periods, without changing the size or dimensions of construction materials. In order to achieve this, the findings were based on the optimal choice of smart glazing that allows to transmit the maximum radiation in winter and the minimum in summer.

The results achieved using the thermal model that the authors have established show that vanadium dioxide glass doped with $5 \%$ tungsten represents the optimal choice in terms of transmitted power $(40 \mathrm{~W} / \mathrm{m} 2$ in summer and 140
$\mathrm{W} / \mathrm{m} 2$ in winter), transmitted energy $(371 \mathrm{Wh} / \mathrm{m} 2)$ in summer and $896 \mathrm{Wh} / \mathrm{m} 2$ in winter), thermal phase shift (4 hours in both summer and winter) and internal temperature $\left(33^{\circ} \mathrm{C}\right.$ in summer and $21^{\circ} \mathrm{C}$ in winter).

\section{Highlights:}

- Thermal analysis of a cubic building design that has smart windows installed has been performed.

- A comparative study of four types of glass (smart windows) has been carried out both in the summer and the winter.

- The optimal choice of smart windows has been determined.

\section{Acknowledgements}

The authors are grateful to Ms. Asmae Essaissi for her modern building design.

This is an Open Access article distributed under the terms of the Creative Commons Attribution License

\section{References}

[1] W.N. Adger, C. Butler, K. Walker-springett, W.N. Adger, C. Butler, K. Walker-springett, C. Butler, K. Walker-springett, Moral reasoning in adaptation to climate change Moral reasoning in adaptation to climate change, Env. Polit. 0 (2017) 1-20. doi:10.1080/09644016.2017.1287624.

[2] B. Richter, D. Goldston, G. Crabtree, L. Glicksman, D. Goldstein D. Greene, D. Kammen, M. Levine, M. Lubell, M. Savitz, D. Sperling, F. Schlachter, J. Scofield, J. Dawson, How America can look within to achieve energy security and reduce global warming, Rev. Mod. Phys. $80 \quad$ (2008) S1-S109. doi:10.1103/RevModPhys.80.S1.

[3] L.A.M. IPCC , in: B. Metz, O.R. Davidson, P. Bosch, R. Dave, Mitigation of climate change: Contribution of working group III to the fourth assessment report of the Intergovernmental Panel on Climate Change, Cambridge University Press, Cambridge, UK, 2007.

[4] Geoffrey B. Smith and Claes-Goran S. Granqvist, GREEN NANOTECHNOLOGY Solutions for Sustainability and Energy in the Built Environment, Taylor and Francis Group, LLC, 2011.

[5] B UILDINGS AND CLIMATE CHANGE : Status, Challenges and Opportunities, United Nations Environment Programme, 2007.

[6] The International Energy Agency (IEA), Technology Roadmap Energy-efficient Buildings: Heating and Cooling Equipment, (2011).

[7] E. M. El Khattabi and M. Mharzi, "Effect of locations and thicknesses for the different material constituting a building wall," Energy Procedia, vol. 139, pp. 328-333, Dec. 2017.

[8] Farooq, Jasim, and Paawan Sharma. "Applications of Building Information Modeling in Electrical Systems Design." Journal of Engineering Science \& Technology Review 10.6 (2017).

[9]I sa, Eleni, and Nicolas Sklavos. "Smart Home Automation: GSM Security System Design \& Implementation." Journal of Engineering Science \& Technology Review 10.3 (2017).

[10]J.A. Leech, W.C. Nelson, R.T. Burnett, S. Aaron, M.E. Raizenne, It's about time: A comparison of Canadian and American timeactivity patterns, J. Expo. Anal. Environ. Epidemiol. 12 (2002) 427-432. doi:10.1038/sj.jea.7500244.

[11] S.M. Babulanam, T.S. Eriksson, G.A. Niklasson, C.G. Granqvist, Thermochromic VO2 films for energy-efficient windows, Sol. Energy Mater. 16 (1987) 347-363. doi:10.1016/01651633(87)90029-3.

[12]G. V. Jorgenson, J.C. Lee, Doped vanadium oxide for optical switching films, Sol. Energy Mater. 14 (1986) 205-214. doi:10.1016/0165-1633(86)90047-X
[13] Y. Gao, C. Cao, L. Dai, H. Luo, M. Kanehira, Y. Ding, Z.L. Wang, Phase and shape controlled VO2 nanostructures by antimony doping, Energy Environ. Sci. 5 (2012) 8708. doi: $10.1039 / \mathrm{c} 2 \mathrm{ee} 22290 \mathrm{f}$.

[14]M. Kamalisarvestani, R. Saidur, S. Mekhilef, F.S. Javadi, Performance, materials and coating technologies of thermochromic thin fi lms on smart windows, Renew. Sustain. Energy Rev. 26 (2013) 353-364. doi:10.1016/j.rser.2013.05.038.

[15]H. Ye, L. Long, Solar Energy Materials \& Solar Cells Smart or not? A theoretical discussion on the smart regulation capacity of vanadium dioxide glazing, Sol. Energy Mater. Sol. Cells. 120 (2014) 669-674. doi:10.1016/j.solmat.2013.10.018.

[16]H. Ye, X. Meng, B. Xu, Theoretical discussions of perfect window , ideal near infrared solar spectrum regulating window and current thermochromic window, Energy Build. 49 (2012) 164-172. doi:10.1016/j.enbuild.2012.02.011.

[17] S.M. Babulanam, T.S. Eriksson, G.A. Niklasson, C.G. Granqvist, Thermochromic VO2 films for energy-efficient windows, Sol. Energy Mater. 16 (1987) 347-363. doi:10.1016/01651633(87)90029-3.

[18]F.J. Morin, Oxides which show a metal-to-insulator transition at the neel temperature, Phys. Rev. Lett. 3 (1959) 34-36. doi:10.1103/PhysRevLett.3.34.

[19]C. Kübler, H. Ehrke, R. Huber, R. Lopez, A. Halabica, R.F Haglund, A. Leitenstorfer, Coherent structural dynamics and electronic correlations during an ultrafast insulator-to-metal phase transition in VO2, Phys. Rev. Lett. 99 (2007) 1-4. doi:10.1103/PhysRevLett.99.116401.

[20]R.J.O. Mossanek, M. Abbate, Optical response of metallic and insulating VO 2 calculated with the LDA approach, J. Phys. Condens. Matter. 19 (2007) 346225. doi:10.1088/09538984/19/34/346225.

[21] O.Y. Berezina, a. a. Velichko, L. a. Lugovskaya, a. L. Pergament, G.B. Stefanovich, Metal-semiconductor transition in nonstoichiometric vanadium dioxide films, Inorg. Mater. 43 (2007) 505-511. doi:10.1134/S0020168507050123.

[22]J. Cao, Y. Gu, W. Fan, L.Q. Chen, D.F. Ogletree, K. Chen, N. Tamura, M. Kunz, C. Barrett, J. Seidel, J. Wu, Extended mapping and exploration of the vanadium dioxide stress-temperature phase diagram, Nano Lett. 10 (2010) 2667-2673. doi:10.1021/nl101457k.

[23] Cavalleri, T. Dekorsy, H. H. W. Chong, J. C. Kieffer, R. W. Schoenlein,"Evidence for a structurally-driven insulator- to-metal transition in VO2: A view from the ultrafast timescale", Physical Review B, 70, (2004). 


\section{El Mehdi El Khattabi, Mohamed Mharzi, Mohammed Zouini and Kęstutis Valančius/ \\ Journal of Engineering Science and Technology Review 11 (5) (2018) 86 - 92}

[24] Gmelin Handbook. Section Vanadium Oxides. 1990;16:482.

[25]Paradis, S., Laou, P., Alain, D., "Doped Vanadium Dioxide with Enhanced Infrared Modulation", Technical Memorandum DRDCVALCARTIER-TM-2007-002, 4 (2007).

[26]L. Kang, Y. Gao, Z. Chen, J. Du, Z. Zhang, H. Luo, Pt/VO2 double-layered films combining thermochromic properties with low emissivity, Sol. Energy Mater. Sol. Cells. 94 (2010) 2078-2084. doi:10.1016/j.solmat.2010.06.023.

[27] J.B.K. Kana, G. Vignaud, A. Gibaud, M. Maaza, Thermally driven sign switch of static dielectric constant of $\mathrm{VO}_{2}$ thin film, Opt. $\begin{array}{llll}\text { Mater. } & \text { (Amst). } & 54 & \text { (2016) }\end{array}$ doi:10.1016/j.optmat.2016.02.032.

[28]A. Ben Chaib, A. Mdaa, I. Zorkani, A. Jorio, Optical properties of the Vanadium dioxide, J. Adv. Phys. 8 (2015) 2148-2155.

[29]A. Ben Chaib, A. Mdaa, I. Zorkani, A. Jorio, Optical properties of a thin layer of the Vanadium dioxide at the metal state, J. Adv. Phys. 9 (2015) 1-8.

[30]A. Ben chaib, Z. Mohammed, I. Zorkani, A. Mdaa, A. Jorio, Study of the Absorptance of a Thin Layer of the Vanadium Dioxide, $\begin{array}{lllll}\text { Indian } & \text { J. Sci. }\end{array}$ doi:10.17485/ijst/2016/v9i48/100111.

[31]Z. Liang, L. Zhao, W. Meng, C. Zhong, S. Wei, Tungsten-doped vanadium dioxide thin fi $\mathrm{lms}$ as smart windows with self-cleaning and energy-saving functions, J. Alloys Compd. 694 (2017) 124 131. doi:10.1016/j.jallcom.2016.09.315.

[32]R. Binions, G. Hyett, C. Piccirillo, I.P. Parkin, Doped and un-doped vanadium dioxide thin films prepared by atmospheric pressure chemical vapour deposition from vanadyl acetylacetonate and tungsten hexachloride: the effects of thickness and crystallographic orientation on thermochromic properties, J. Mater. Chem. 17 (2007) 4652. doi:10.1039/b708856f

[33] W. Burkhardt, T. Christmann, B.. Meyer, W. Niessner, D. Schalch, A. Scharmann, W- and F-doped $\mathrm{VO}_{2}$ films studied by photoelectron spectrometry, Thin Solid Films. 345 (1999) 229-235. doi:10.1016/S0040-6090(98)01406-0.

[34] T.D. Manning, I.P. Parkin, M.E. Pemble, D. Sheel, D. Vernardou, Intelligent Window Coatings: Atmospheric Pressure Chemical Vapor Deposition of Tungsten-Doped Vanadium Dioxide, Chem.
Mater. 16 (2004) 744-749, doi:10.1021/cm034905y.

[35] L. Zhao, L. Miao, C. Liu, C. Li, T. Asaka, Y. Kang, Y. Iwamoto, S Tanemura, H. Gu, H. Su, Solution-Processed VO2-SiO2 Composite Films with Simultaneously Enhanced Luminous Transmittance, Solar Modulation Ability and Anti-Oxidation property, Sci. Rep. 4 (2015) 7000. doi:10.1038/srep07000.

[36]C. Batista, R.M. Ribeiro, V. Teixeira, Synthesis and characterization of VO2-based thermochromic thin films for energy-efficient windows., Nanoscale Res. Lett. 6 (2011) 301. doi:10.1186/1556-276X-6-301.

[37] Jannot, Y., Solar Thermal, Courses and Exercises, Chapter: Solar Energy, Chapter: bibliography: Radiation Geo- metrical Form Factors, October 2003

[38] S.M.A. Bekkouche, T. Benouaz, M.K. Cherier, M. Hamdani.Thermal resistances of local building materials and their effect upon the interior temperatures case of a building located in Ghardaïa region. Construction and Building Materials 52 (2014) 59-70

[39]ITO (N.) et KIMURA (J.O.). - A field experiment study on the convective heat transfert coefficient on exterior surface of a building. ASHRAE Transaction, (2225), (1972).

[40] M. Mharzi, M. Daguenet, and S. Daoudi, "Thermosolutal natural convection in a vertically layered fluid-porous medium heated from the side," Energy Conversion and Management, vol. 41, no. 10, pp. 1065-1090, Jul. 2000

[41]Gilles LEFEBVRE-Comportement thermique dynamique des bâtiments : simulation et analyse-Techniques de l'Ingénieur, traité Génie énergétique

[42]Long, Linshuang, and Hong Ye. "How to be smart and energy efficient: A general discussion on thermochromic windows." Scientific reports 4 (2014).

[43]Zhang, Jing, et al. "Mesoporous $\mathrm{SiO} 2 / \mathrm{VO}_{2}$ double-layer thermochromic coating with improved visible transmittance for smart window." Solar Energy Materials and Solar Cells 162 (2017): 134-141.

[44]Zhou, Jiadong, et al. "VO2 thermochromic smart window for energy savings and generation." Scientific reports 3 (2013): 3029. 